\title{
Ruhsal Liderliğin İş Tatmini Üzerindeki Etkisini Farklı Kuşaklar Üzerinden İnceleme ${ }^{12}$
}

\author{
Alper DEMIRDAĞ ${ }^{3}$ Şafak GÜNDÜZ ${ }^{4}$
}

Başvuru Tarihi: 27.01 .2020

Kabul Tarihi: 16.02 .2021

Makale Türü: Araştırma Makalesi

\section{Öz}

Bu araştırmanın amacı ruhsal liderliğin iş tatmini üzerindeki etkisini farklı kuşaklar bazında incelemektir. Ruhsal Liderlik Ölçeği ve İş Tatmininin sosyodemografik bilgilere göre farklılık gösterip göstermediğinin sinandiğr bu araştırma, nicel verilere dayalı tarama modellerden ilişkisel tarama modelinde tasarlanmıştır. Ölçüm aracı olarak, Fry'ın 40 maddelik Ruhsal Liderlik Ölçeği ile 18 maddelik Minnesota İş Tatmini Ölçeği kullanılmıştır. Toplanan verilerin analiziyle elde edilen bulgulara göre, ruhsal liderlik arttıkça iş tatmini de artmaktadır. Y kuşağının ruhsal liderlik algısı toplam 9 boyutun 5 'inde X kuşağına göre daha yüksektir. İș tatmini algısı puanları değerlendirildiğinde Y kuşağının iş tatmini algısının sadece içsel tatmin boyutunda X kuşağından daha yüksek olduğu görülmektedir. Ruhsal liderliğin iş tatmini üzerindeki etkisini farklı kuşaklar üzerinden incelemesine atıfta bulunan bu çalışma, X ve Y kuşaklarının ruhsal liderlik ve iş tatmini algıları arasında kısmi farklılık olduğunu ortaya koymaktadır. Ruhsal liderliğin iş tatminini pozitif yönde etkilediği literatürü destekler biçimde bir kez daha görülmüştür.

Anahtar Kelimeler: Ruhsal Liderlik, İş Tatmini, Kuşaklar

Atıf: Demirdağ, A. ve Gündüz, Ş. (2021). Ruhsal liderliğin iş tatmini üzerindeki etkisini farklı kuşaklar üzerinden inceleme. Anadolu Üniversitesi Sosyal Bilimler Dergisi, 21(1), 99-118.

\footnotetext{
${ }^{1} 2019$ yılına ait tezden üretildiği için etik kurul izni gerekmemektedir.

${ }^{2} \mathrm{Bu}$ çalışma yazarın yüksek lisans tezinden türetilmiştir.

${ }^{3}$ Maltepe Üniversitesi Lisansüstü Eğitim Enstitüsü İşletme Anabilim Dalı, email2alper@gmail.com, ORCID: 0000-0001-5747-7131

${ }^{4}$ Maltepe Üniversitesi İşletme ve Yönetim Bilimleri Fakültesi, safakgunduz@maltepe.edu.tr, ORCID: 0000-0002-2589-8780
} 


\title{
Analysing the Impact of Spiritual Leadership on Job Satisfaction Through Different Generations
}

\author{
Alper DEMIRDAĞ5 ${ }^{5}$ Şafak GÜNDÜZ
}

Submitted by: 27.01 .2020

Accepted by: 16.02 .2021

Article Type: Research Article

\begin{abstract}
The aim of this study is to examine the effect of spiritual leadership on job satisfaction in different generations. This study was designed to investigate whether the Psychological Leadership Scale and Job Satisfaction differ according to sociodemographic variables. Fry's 40-item Spiritual Leadership Scale and 18-item Minnesota Job Satisfaction Scale were used. It was found that job satisfaction increases when spiritual leadership perception increases. The spiritual leadership perception of the Generation $Y$ is higher in 5 of the 9 dimensions compared to the Generation X. When the perception of job satisfaction scores are evaluated, it is seen that the Generation $Y$ is higher than the Generation X only in the internal satisfaction dimension. This study, which refers to the effect of mental leadership on job satisfaction over different generations, reveals that there is a partial difference between the perceptions of spiritual leadership and job satisfaction of the Generations X and Y. It was once again seen that spiritual leadership positively affects job satisfaction, in support of the literature.
\end{abstract}

Keywords: Spiritual Leadership, Job Satisfaction, Generations

\footnotetext{
${ }^{5}$ Maltepe University Graduate School Business Administration, email2alper@gmail.com, ORCID: 0000-0001-5747-7131

${ }^{6}$ Maltepe University Faculty of Business and Management Sciences, safakgunduz@maltepe.edu.tr, ORCID: 0000-0002-2589-8780
} 


\section{Giriş}

İş yaşamının gün geçtikçe artan yoğun ve karmaşık yapısında İşletme disiplini de ilgisini çalışanların iş yerinde yaşamını nelerin daha anlamlı kılabileceğine yöneltmiş ve ruhsal liderlik konusunda araştırmalar artmıştır. Çalışanların iş tatmininde etkili olabilecek unsurları, özellikle de liderlik ile iş tatmini arasındaki ilişkiyi araştıran çok sayıda çalışma mevcuttur (Gündüz, 2016). Bu bağlamda ruhsal liderlik ile iş tatmini arasındaki ilişkiyi irdelemek mevcut literatüre katkı sağlayacaktır. Farklı kuşakların bir arada çalıştığı iş yaşamında, kuşaklar arasında ruhsal liderlik algılarındaki ve iş tatmini algıları arasındaki farklılıkları tespit etmek, işletme disiplinine ve profesyonellere yol gösterici nitelikte olabilecektir. Literatürde, demografik özelliklerden yaşın iş tatmini düzeyinde nasıl bir fark yarattığına ilişkin pek çok çalışma mevcuttur (Toker, 2007; Friday ve Friday, 2003). Bu çalışmaların büyük kısmı yaş arttıkça iş tatmininin de arttığını göstermektedir. Bu çalışmada ise yaş değişkeni, $\mathrm{X}$ ve $\mathrm{Y}$ kuşağı ayrımı ile belirtilerek hangi kuşağın iş tatmininin daha fazla olduğu tespit edilerek kuşak çalışmalarına katkı sağlanacaktır.

Gerek işletme disiplininde, gerekse profesyonel iş yaşamında oldukça dikkat çeken liderlik kavramı, ticari türbülanslarda da etkili olduğu için sermaye sahiplerinin dikkatini çekmekte ve insan kaynaklarının planlarını etkilemektedir (Parameshwar, 2005; Strack ve ark., 2000). Gelişen teknoloji, güncel hayattaki olumlu etkilerinin yanı sıra olumsuzluklara da yol açmaktadır ve birtakım eksiklikleri mevcuttur. Bu eksikler içerisinde önemle dikkate alınması gereken bir kavram maneviyattır. Maneviyat, bireysel ve insan odaklı bir kavramdır. Her insan, maneviyatı zihniyetiyle şekillendirip tanımlayabilmektedir (Dent ve ark., 2005; Strack ve ark., 2002; Freeman, 2011). Maneviyat, ruhsal liderliğin temelini oluşturarak iş yerlerindeki gelişimi arttırmakta ve dolayısıyla iş doyumuna katkı sağlamaktadır (Dent ve ark., 2005; Cook-Greuter, 2002; Sanders ve ark., 2003). Bu çalışma, ruhsallığı liderliğin ayrılmaz bir parçası olarak temellendirmekte; ruhsallığı bütünleşik bir liderlik geliştirme modelinin değişkeni olarak kuşaklar bazında irdeleyerek ruhsal liderlik ile iş tatmini arasındaki ilişkiyi ortaya koymaktadır.

\section{Kavramsal Çerçeve}

\section{Ruhsal liderlik}

Liderlik Kuramı, milattan önceki yıllarda “Özellik Kuramı” ile başlayarak 1940”lı yıllara kadar devam etmiş, 1940-1960 arası "Davranışsal Kuram" ile lider davranışları konuya dahil edilmiş, 1960-1980 arasında ise "Durumsal Kuram" ile liderlerin çevreleriyle etkileşimleri ve bunun sonuçları irdelenmiştir. 1980 ve sonrası "Yeni Yaklaşımlar" kavramı ile (Koçel, 2001), 21. yüzyılın yeniliklerine adapte olabilen Y ve Z kuşağının karakteristik özellikleri gelişim göstermiş ve kuşaklarda yaşanan bu değişim liderliği etkilemiştir (Serinkan, 2012).

Son yıllarda iş ortamlarında ekonomik krizlerle birlikte kendini gösteren aşırı stresli yaşam tarzı sonucu, rutin hayattan zevk almama (Demircioğlu, 2015), kolay tatmin olmama (Aslan-Yılmaz ve Dönmez, 2013) ve dışlanma duygusuna yol açmış ve böylece, geleneksel liderlik anlayışından uzaklaşılarak manevi liderlik anlayışına doğru yönelinmiştir (Baloğlu ve Karadağ, 2009; Marx, 2006). Uzun zamandır ihmal edilmiş bir alan olan maneviyatın liderlik teorilerine dâhil edilmesi liderin değerleri, tutumları ve davranışları yoluyla başkalarının motive etmesi hedeflenmiştir (Fry, 2003). Tek bir liderlik çeşidi üzerinde uzlaşılamaması liderlik kavramında farklı teorilerin ortaya çıkmasına yol açmıştır. Maneviyat duygusunun liderlik ile bütünleşmesi fikrinden yola çıkan Ruhsal Liderlik de bu teorilerden biri olarak gündeme gelmektedir (Fry ve ark., 2017).

Kişisel özelliklerin, umudun, inancın, maneviyatın, anlam, özgecil sevgi ve aitlik hissi boyutlarının liderlik ile bütünleşmesi ile ortaya çıkan ruhsal liderlik modelinde kişisel vizyon ile ruh birleşir (Fry, 2003). Ruhsal liderlik modelinde, vizyon, kişinin hayatında ulaşmak istediği hedeftir (Chen ve Yang, 2012). Böylece aynı vizyona sahip çalışanların umut ve inanç duyguları ile hedeflerine ulaşacaklarına ve yaptıkları işleri başaracaklarına 
dair kendine olan güvenleri artar ve ortak duyguları ruhsal olarak temellenir (Fry ve ark., 2017). Ruhsal olarak hedeflerine ulaşmaya hazır bireyler için hedeflerine ulaşmak ödül almak gibidir. Örgüt içinde ödül olarak görülen bu ortak duygu, çalışanların sağlam bir inanca sahip olması sayesinde kişisel ve örgütsel vizyonlarının daha fazla güçlenmesine yol açmaktadır (Chen ve Yang, 2012).

Ruhsal lideri olan çalışanların, ortak ve net vizyon nedeniyle daha iyi performans gösterme olasılı̆̆ daha yüksektir (Gündüz, 2017). Ruhsal liderlik, örgüt içinde uzun vadeli bir mücadeleyi ve farklı bir geleceği vadederek motivasyonu arttırır. Lider için bu noktada yapılması gereken verilen vaatleri gerçekleştirerek takipçilerinin tatmin duygusunu yükseltmek ve yaptıkları işten keyif almalarını sağlamaktır. Motivasyonu yükselen çalışanlar, performanslarını geliştirmek için kendilerini zorlayacak hedefleri isterler (Locke, 1976). Basit işleri yapmayı tercih etmezler, çünkü işlerini ve işyerini severler. Görev ve sorumluluk alarak, kendilerine güvenerek, kendilerini ve yaşamayı severek (Allen, 1972), inançları ve ruhsal özgürlükleri sayesinde zor işlerin üstesinden gelebileceklerini düşünerek işlerin kararlılıkla yaparlar.

Ruhsal liderlik diğer liderlik türlerinde olduğu gibi farklı seviyelerde görülmektedir (Corgnet ve ark., 2015). Ruhsal liderlik modeli genel olarak, kendine güvenmeyi ön plana koyan ve zorlu görevlere karşı işini severek ve mükemmeliyetçi bir tutumla yapan ve yaptığı işin altından kalkan bireyleri motive etmek üzerinedir (Yang ve ark., 2017). Ruhsal liderliğin temelinde beden, akıl, kalp ve ruh bulunmaktadır (Moxley, 2000). Bu dört ana nokta aynı zamanda insan varlığının da merkezini oluşturmaktadır ve kişilerden yüksek düzeyde verim alabilmek için kullanılmaktadır (Harvard Business School Publishing, 2015). Ruhsal lider, çalışanın bu dört öğeyi bir araya getirerek maneviyat elde etmesini sağlar, bu da kişinin yaptığı işten keyif almasını sağlar (Vu ve Gill, 2018; Gündüz, 2017).

Çalışan birey çoğunlukla, kendini geliştirebileceği, kişisel motivasyonunu arttırabileceği, maddi ve manevi duygularını tatmin ederek kendisine hitap eden bir iş ve yeteneklerini sergileyebileceği bir çalışma ortamı arar (Goleman, 2007). Yaptığı işteki rolü ile iş yaşamı dışında sahip olduğu rollerin uyum içinde olması bireyin mutluluk duygusunu arttırırken aynı zamanda da işyerindeki üretkenliğin de devamlılığını sağlayarak, çalışanların işten kopmalarını ve soğumalarını engeller (Giacalone ve Jurkiewicz, 2003).

Ruhsal liderlik, çalışanlar tarafından arzulanan ortak bir vizyon oluşmasına (Hoppock, 1935) ilham vermesi nedeniyle (Fry, 2003) iş tatminini yükselterek çalışanlara işyerinde hayallerini gerçekleştirebilme umudu verir (Weng ve ark., 2015). İş tatmini, işin özellikleri ile çalışanların beklenti ve isteklerinin kesiştiği noktada gerçekleşir. Yoğun rekabetin yaşandığı günümüzde, örgütlerin ayakta kalabilmeleri ve rekabet edebilmeleri sahip oldukları kaynakları en etkili ve verimli biçimde kullanmalarına bağlıdır (Aşık, 2010). Ruhsal lider, kişinin kendisine ve bulunduğu ortama bir şekilde her zaman katkı sağlamasını bekler (Fry, 2003). İşyerine geldiğinde sevinen, kendini evinde gibi hisseden, işyerinde gördüğü saygıdan memnun olan ve bu duygularla her gün işine giden çalışanlar, işyerinde karşılarına gelen karmaşık ya da zor problemleri çözme konusunda daha arzulu olurlar ve işleri verimli şekilde yaparlar (Rose ve ark., 2016).

Ruhsal liderlik teorileri ilk ortaya çıktığında, ABD iş dünyasında yayınlanan ruhsal liderlik çalışmaları, istenilen ve beklenilen ilgiyi görmemiş ve ruhsal liderlik teorileri için sığ düşüncelere bağlı varsayımlar olduğu eleştirileri yapılmış (Hoppe, 2005), ancak yine de bu teori üzerine yapılan araştırmalara destek verilmiştir (Pratt, 2000).

\section{iş tatmini}

İsteklerin gerçekleşmesi ile kişide oluşan mutluluk düzeyine ya da yeterli doygunluğa ulaşmaya tatmin denir. İş tatmini de çalışanın işini yaparken sahip olduğu mutluluk düzeyi ya da işine hissettiği doygunluk derecesi olarak ifade edilebilir (Yüksel, 2007). İş tatmini, çalışanın işine devam edip etmeyeceğini belirler ve çalışma ortamını düzenleyerek yönetimin alacağı kararlarda çalışanlara karşı güç verir (Wnuk, 2017). 
1935’te Hoppock tarafından yayınlanan “Job Satisfaction” isimli makalede iş tatmini "bir kişinin gerçekten işinden tatmin olduğunu söylemesini sağlayacak tüm psikolojik, fizyolojik ve çevresel koşullar” olarak tanımlanmaktadır. Bir diğer ifadeyle çalışanların yaptıkları işlerden elde ettikleri memnuniyet ve mutluluk düzeyine iş tatmini denir. İş tatmini, çalışanların işlerine karşı hissettikleri duygusallığın (Vroom, 1964), iş yaparken aldıkları hazzın, mutluluğun ve iş yerine karşı gelişen aidiyet duygusunun bütünü olarak da betimlenebilir (Ülker ve Özdemir, 2016). İş tatmini kişilerin istekleri, hedefleri, beklentileri ve ihtiyaçları ile performansları arasındaki ilişki hakkında fikir verir (Özdemir ve ark., 2016).

Fiziksel iyileştirme yaparak üretimde verimlilik artışı olabileceği fikri üzerine 1924 yılında başlanan ve 1934 yllına kadar devam eden Hawthorne deneylerinin, tahmin edilenin aksine, fiziksel iyileştirme yapılmasının üretimde verimlilik artışına sebep olmadığını ortaya koyması (Ataman, 2009) araştırmaların sosyal etkenlere kayarak, çalışanların çalışma hayatındaki psikolojilerinin çalışmalarına yansıyabileceği varsayımı üzerinde yoğunlaşmasına yol açmıştır (Mucuk, 2003).

Psikoloji, sosyoloji, işletme, örgütsel davranış gibi pek çok disiplinin ilgi odağı haline gelen iş tatmini, çalışanların içsel (duygulara ait) ve dışsal (ifadeye ait) hislerinin meydana getirdiği tepkiler bütünüdür. Tepkilerin pozitif veya negatif olması, şiddeti, biçimi örgüt ve çalışanlar arasında oluşturulan bağ ile şekillenmektedir (Özpehlivan, 2018). İş tatmini üzerine yapılan araştırmalar işin kendi niteliğini temel alan içsel iş tatmini ve işin çevre etkenlerini (yönetici, iş arkadaşları vb.) temel alan dışsal iş tatmini üzerine yoğunlaşmıştır (Lawler ve Porter, 1967; Gemmil ve Heisler, 1972; Deutsch, 1975; Feldman ve Arnold, 1985; Bogler, 2001).İş tatminini etkileyen unsurlar kişisel etkenler, sosyal etkenler (çalışma arkadaşları, etkileşim fırsatları), örgütsel etkenler (ücret, yapılan işin niteliği, yönetim tarzı, yükselme olanakları) ve çevresel etkenler (ekonomik, teknolojik, yasal) olarak sıralanabilir (Mullins, 1996).

Sosyal sermayenin, diğer bir deyişle çalışanların rekabet üstünlüğü sağlayan bir unsur olarak görüldüğünden hareketle, örgütte iş tatmininin sağlanamamasının örgütün sürdürülebilirliğini tehlikeye sokan bitr etmen olduğu söylenebilir. İş tatmininin verdiği sağladığı doyum, çalışanın performansını arttırabileceğinden örgütsel başarıda da etkili olacağı şeklinde bir değerlendirme yapılabilir (Vecchio,1988).

\section{Bir Demografik Değişken Olarak "Kuşak"}

Kuşak kelimesi, "yaklaşık yirmi beş-otuz yıllık yaş kümelerini oluşturan bireyler öbeği, göbek, nesil, batın, jenerasyon” anlamına gelmektedir (TDK, 2019). Kuşak kavramının tarihsel temelleri eski uygarlıklardan itibaren atılmış (Özer ve ark., 2013); kişiler arası periyodik ve sistemli farklılıklardan ortaya çıkmış, tarih, sosyoloji, psikoloji ve yönetim bilimi gibi alanlara inceleme konusu olmuştur (Adıgüzel ve ark., 2014). Kuşaklar birbirinden sadece o kuşağa ait bireylerde olan özellikler ile ayrılır (Toruntay, 2011). Kuşaklar arasında kişilerin yaşadıkları ortama ve sosyal çevrelerine, aldıkları eğitime ve gelecekten beklentilerine göre değişimler gözlenebilir. Farklı kuşakların birbirinden farklı şahsi bakış açısı olmasıyla birlikte aynı zamanda şahsına münhasır davranışları, güçlü ya da zayıf yanları bulunur. Birbirine yakın yıllarda doğmuş ve benzer deneyimleri yaşamış kişiler kendilerini aynı dönemin insanları olarak görürken, diğerleri farklı kuşak mensubu olarak adlandırılır. Kuşaklar, çok çeşitli sınıflandırmalara tabi tutulmakla birlikte bu çalışmada Sessiz Nesil (1925-1945), Bebek Patlaması (1946-1964), X Kuşağı (1965-1979), Y Kuşağı (1980-1999) ve Z Kuşağı (2000 ve sonrası) şeklinde sınıflandırılarak incelenmiştir (Yüksekbilgili, 2013).

Sessiz Nesil: 1925-1945 arası doğan sessiz nesil mensupları, bilgili, muhafazakâr, disiplinli, sorumluluk duygusu yüksek, keşfetme yeteneği gelişmiş bireylerdir (Tolbize, 2008). Kuşak, güven duygusunu önemsemektedir. Daha çok direktif alarak çalışır (ERC Raporu, 2011). İş hayatında aktif oldukları dönem sınırı en son 2010 olarak çizilmiştir (Adıgüzel ve ark., 2014). 
Bebek Patlaması: 1946-1964 yılları arasında doğanlardan oluşan bebek patlaması kuşağının kendi kendilerini motive edebilen ve takdir edilmekten hoşlanmayan bir yapıya sahip oldukları söylenebilir. Maaş öncelikleridir. Takım çalışmasına önem verirler (Acılığlu, 2015).

X Kuşağı: 1965 ile 1979 yılları arasında doğanlardan oluşan X kuşağı aynı zamanda geçiş kuşağı olarak da adlandırılır (Alwin, 2002). Genellikle bağımsızlıklarına düşkün ve sonuç odaklıdırlar. Kendisini sıkacak işlerden uzak durarak zamanın koşullarına ayak uydurmaya çalışırlar (Dias, 2003). Erkeklerin kadar kadınların da iş yaşamında aktif olmaya başladıkları gözlemlenmektedir. Birden fazla kariyer yapmayı tercih etmektedirler. İş yaşamında güvenlik ve maaş unsurlarını ön planda tutmaktadırlar.

Y Kuşağg: 1980-1988 arası doğan Y kuşağının dörtte birinin ebeveynleri en az üniversite eğitimi almışken, üçte biri boşanmış anne ve babaya sahiptir (Zemke ve ark., 2013). Teknolojiyi kendisinden önceki kuşaklara göre çok daha iyi kullanır ve teknoloji hayatlarının bir parçasıdır (Mengi, 2018).

Z Kuşağı: 1999-2012 arası doğan Z kuşağı çağımızın en genç çalışanlarını oluşturmaktadır (Kuran, 2018). Z kuşağının sosyal ve iş yaşamındaki davranışları yeni araştırmalar neticesinde belirlenmeye çalışılmaktadır, zira şimdiye kadar yeterince bilgi kaynağına sahip olunmamıştır. Tam anlamıyla teknolojinin hâkim olduğu süre içinde doğup büyüdükleri için teknolojiyi doğdukları andan itibaren kullanan kişilerden oluşur (Levickaite, 2010).

\section{Yöntem}

\section{Değişkenler ve Hipotezler}

Çalışmanın bağımlı değişkeni iş tatmini iken bağımsız değişkeni X ve Y kuşağı sosyo-demografik özellikleridir. Literatürde X kuşağı iş tatmini düzeyinin Y kuşağına göre daha yüksek olduğu belirtilmektedir (Koç ve ark., 2016, s.181). Bu araştırmada X ve Y kuşaklarında ruhsal liderliğin ne şekilde önemli olduğu ve iki kuşak arasında iş tatmini bakımından önemli bir fark olup olmadığını tespit etmek amacıyla şu araştırma soruları oluşturulmuştur:

1. Ruhsal liderlik faktörleri ile iş tatmini faktörleri arasında pozitif yönlü bir ilişki var mıdır?

2. X ve $\mathrm{Y}$ kuşağının ruhsal liderlik algıları farklılık göstermekte midir?

3. X ve $Y$ kuşağının iş tatmini düzeyleri farklılık göstermekte midir?

Araştırma kapsamında yaş harici başka sosyodemografik değişkenlere ait sorular yöneltilmiş olsa da bu verilerden elde edilen bulgular çalışmaya dâhil edilmemiştir.

\section{Örneklem ve Veri Toplama}

Araştırmada kullanılan veri toplama araçlarının uygulanması için 322 kişiye online anket yöntemiyle ulaşılmıştır (Çalışma 2019 yılına ait tezden üretildiği için etik kurul izni gerekmemektedir.). Kişisel Bilgi Formu, Ruhsal Liderlik ve İş Tatmini Ölçekleri uygulanmıştır. Online anket uygulamasının başında araştırmacının amacı hakkında bilgi verilmiştir. Araştırma sonuçlarının geçerlik ve güvenirliği açısından içten bir şekilde cevaplandırmalarının önemli olduğu ve bireysel bilgilerin gizli tutulacağı belirtilmiştir.

Araştırmanın evreni tüm çalışanlar olmakla beraber bu çalışmanın sınırlılığı olarak BİST 500 şirketlerindeki çalışanlar belirlenmiş olup araştırmaya katılanların büyük çoğunluğu özel sektördeki çalışanlardır. Gerek kamu gerekse özel sektörden de eşit oranda katılımın olmaması araştırma kısıtı oluşturmuştur. Ölçeklerdeki ifadelerin araştırmaya katılanlar tarafından doğru anlaşıldığı, verilen cevapların gerçeği yansıttığı ve herhangi bir baskı altında kalmadan verildiği varsayılmaktadır. Araştırmanın örneklem büyüklüğü belirlerken, hedef kitleyi belirlemek olanaksız olduğunda, ya da çalışmanın genelleme amacı taşımamasından dolayı hedef kitledeki birey sayısının bilinmediği durumlardaki formül kullanılmıştır: 


$$
n=\frac{z_{\alpha / 2}^{2} \cdot p \cdot q}{d^{2}}
$$

Burada (Gündüz, 2016);

n: örnekleme alınacak birey sayısı

p: incelenen olayların görülüş sıklığ1 (gerçekleşme olasılığı)

q: İncelenen olayların görülmeyiş sıklığı (gerçekleşmeme olasılığı)

d: olayın görülüşs sıklığına göre kabul edilen örnekleme hatası (genellikle \%5)

z: $\alpha$ anlamlılık düzeyinde, $\mathrm{z}$ tablosuna göre bulunan teorik değer.

BİST 500 şirketlerinde 1 milyonun üzerinde olan çalışan sayısına (Hürriyet, 2018) göre hesaplanan örneklem büyüklüğ̈̈

$\mathrm{n}=(1,96)^{2}(0,20 \mathrm{x} 0,80) /(0,05)^{2}=246^{\prime} \mathrm{d} 1 \mathrm{r}$.

Ankete dönüşün aksayacağı ihtimaline karşı 400 anket dağıtılmış ve 322 dönüş sağlanmıştır. Anket formu aracılığgyla elde edilen veriler "SPSS for Windows 22.0” programında analiz edilmiştir.

\section{Ölçüm Araçlarının Güvenilirliği, Geçerliliği ve Oluşan Faktörlerin Analizi}

Bu tez çalışmasında Fry’ın 40 maddelik Ruhsal Liderlik Ölçeği ile Minnesota İş Tatmini Ölçeği geçerliliği, faktör analizi ve güvenirlik teknikleri ile sınanmıştır.

Ruhsal Liderlik Ölçeği ile toplanan verilerin, faktör analizine uygunluğu için yapılan Kaiser-Meyer-Olkin (KMO) testi sonucu KMO değeri $\mathrm{KMO}=0,957$ olarak bulunduğundan, ölçüm aracının faktör analizi için uygun olduğu anlaşılmıştır. Değişkenler arasında yeterli oranda ilişki olduğunu test etmek amacıyla uygulanan Bartlett Küresellik Testinde p<0,001 olduğundan, değişkenler arasında anlamlı bir ilişki olduğu görülmektedir.

KMO uygunluk testi sonrası, Varimax Rotasyon Tekniği kullanılarak yapılan birinci faktör analizi ile ölçüm aracının 40 maddesinin 9 alt boyutta toplandığı ve alt boyutların toplam varyansın \%79,63’ünü açıkladı̆̆1 bulunmuştur. Bu analizlerde ilgili yazılımın önerdiği biçimde Öz Değer 1 olarak tercih edilmiştir. Faktör analizinin ilk sonuçlarında minimum faktör yük değerinin 0,30'dan büyük olduğu gözlenmektedir. Maddelerle ilgili olarak tanımlanan dokuz faktörün ortak varyanslarının (communalities) ise 0,402 ile 0,764 arasında değiştiği gözlenmektedir. Buna göre, analizde Fry’ın ölçeği ile paralellik gösterir biçimde ortaya çıkan dokuz faktörün, maddelerdeki toplam varyansın ve ölçeğe ilişkin varyansın çoğunluğunu açıkladığı görülmektedir. Ancak, ölçüm aracında yer alan 23, 31, 36, 37, 39 ve 40 numaralı maddelerinin 9 faktörde (boyutta) birden faktör yükü aldığı görülerek, bu maddelerin ölçekten çıkarılmasına karar verilmiştir. Tekrar yapılan faktör analizi sonucu (Tablo 1) "Vizyon" alt boyutunun toplam varyansın \%43,21'ini; "Umut/Çaba” alt boyutunun toplam varyansın \%7,08'ini; “Özgecil Sevgi” alt boyutunun toplam varyansin \%5,20'sini; “Anlam” alt boyutunun toplam varyansın \%4,92'sini; “Üyelik/Aitlik” alt boyutunun toplam varyansin \%4,43'ünü; "Ruhsal Yaşam” alt boyutunun toplam varyansın \%4,34'ünü; “Kurumsal Bağlılık” alt boyutunun toplam varyansın \%3,97'sini; "Verimlilik" alt boyutunun toplam varyansın \%3,25'ini; ve "Yaşamsal Memnuniyet" alt boyutunun toplam varyansın \%3,12'sini açıkladı̆̆ı bulunmuştur. 
Tablo 1.

Ruhsal Liderlik Ölçeği Faktör Yükleri (Varimax Döndürülmüş Faktör Matrisi)

\begin{tabular}{|c|c|c|c|c|c|c|c|c|c|c|}
\hline & & 1 & 2 & 3 & 4 & 5 & 6 & 7 & 8 & 9 \\
\hline \multicolumn{11}{|c|}{ Faktör 1 Vizyon } \\
\hline 18 & $\begin{array}{l}\text { Çalıştığım kurumun vizyonunu } \\
\text { anlıyorum ve bu vizyona kendimi } \\
\text { adadım. }\end{array}$ & 0,701 & & & & & & & & \\
\hline 26 & $\begin{array}{l}\text { Kurumumu vizyonu beni, içimdeki } \\
\text { en iyiyi çıkarmaya teşvik eder. }\end{array}$ & 0,638 & & & & & & & & \\
\hline 28 & $\begin{array}{l}\text { Kurumumun vizyonu açık ve beni } \\
\text { zorlayıcıdır. }\end{array}$ & 0,620 & & & & & & & & \\
\hline 30 & $\begin{array}{l}\text { Kurumumun vizyonu benim en } \\
\text { yüksek performansımı sergilememe } \\
\text { neden olur. }\end{array}$ & 0,594 & & & & & & & & \\
\hline
\end{tabular}

\section{Faktör 2 Umut/Çaba}

8 Kurumuma inanırım ve kurumumun

misyonunu başarması için "gereken

ne olursa olsun" yapmaya

gönüllüyüm.

15 Kurumumun tüm ideallerine

inanırım, bu nedenle kurumumun

başarısına yardım etmek için

azimliyim ve çok fazla çaba harcarım.

16 Başarmamıza yardımcı olabilecek her

şeyi yaparak kurumuma ve onun

misyonuna olan inancımı

kanitlyyorum.

\section{Faktör 3 Özgecil Sevgi}

1 Kurumumdaki liderler konuştuğu 0,764

gibi hareket ederler, liderlerimizin

özü sözü birdir.

10 Kurumumuzdaki liderler dürüst ve alçak gönüllüdür.

12 Kurumum güvenilir bir yerdir ve $\quad 0,716$ çalışanlarına karşı vefalıdır.

22 Kurumumdaki liderler, çalışanların $\quad 0,683$ haklarını koruyacak cesarete sahiptir.

\begin{tabular}{|c|c|c|}
\hline & ör 4 Anlam & \\
\hline 2 & $\begin{array}{l}\text { Yaptığım iş insanların yaşamında } \\
\text { farklar yaratır. }\end{array}$ & 0,764 \\
\hline 14 & Yaptığım iş benim için anlamlıdır. & 0,708 \\
\hline 17 & $\begin{array}{l}\text { Yaptığım iş benim için oldukça } \\
\text { önemlidir. }\end{array}$ & 0,703 \\
\hline Fal & ör 5 Üyelik/Aitlik & \\
\hline 3 & $\begin{array}{l}\text { Kurumumun beni ve işimi takip } \\
\text { etiğini hissederim. }\end{array}$ & 0,757 \\
\hline 9 & $\begin{array}{l}\text { Kurumumun bana ve işime sayg1 } \\
\text { duyduğunu hissederim. }\end{array}$ & 0,730 \\
\hline 21 & $\begin{array}{l}\text { İşimden dolayı önemsendiğimi } \\
\text { hissederim. }\end{array}$ & 0,695 \\
\hline 32 & $\begin{array}{l}\text { Liderlerim tarafından son derece } \\
\text { saygı gördügümü hissederim. }\end{array}$ & 0,582 \\
\hline
\end{tabular}


Tablo 1.

Ruhsal Liderlik Ölçeği Faktör Yükleri (Varimax Döndürülmüş Faktör Matrisi) (Devamı)

\begin{tabular}{|c|c|c|c|c|c|}
\hline \multicolumn{6}{|c|}{ Faktör 6 Ruhsal Yaşam } \\
\hline 5 & Yaşam için umut doluyum. & 0,748 & & & \\
\hline 13 & $\begin{array}{l}\text { İş arkadaşlarımın ruhsal sağlıklarına } \\
\text { dikkat ederim. }\end{array}$ & 0,713 & & & \\
\hline 25 & $\begin{array}{l}\text { Kendimi manevi değerleri olan bir } \\
\text { kişi olarak görürüm. }\end{array}$ & 0,646 & & & \\
\hline 34 & $\begin{array}{l}\text { Manevi uygulamalar yürütürüm } \\
\text { (ibadet, doğada zaman geçirme, } \\
\text { meditasyon, yoga, günlük yazma vb.) }\end{array}$ & 0,559 & & & \\
\hline 38 & $\begin{array}{l}\text { Manevi değerlerim yaptığım } \\
\text { seçimleri etkiler. }\end{array}$ & 0,402 & & & \\
\hline \multicolumn{6}{|c|}{ Faktör 7 Kurumsal Bağlılık } \\
\hline 4 & $\begin{array}{l}\text { Bu kurumda kendimi aileden biri gibi } \\
\text { hissederim. }\end{array}$ & & 0,754 & & \\
\hline 7 & $\begin{array}{l}\text { Kurumun sorunlarını gerçekten } \\
\text { kendi sorunummuş gibi hissederim. }\end{array}$ & & 0,740 & & \\
\hline 11 & $\begin{array}{l}\text { Meslek hayatımın geri kalanını bu } \\
\text { kurumda geçirirsem mutlu olurum. }\end{array}$ & & 0,719 & & \\
\hline \multicolumn{6}{|c|}{ Faktör 8 Verimlilik } \\
\hline 19 & $\begin{array}{l}\text { Çalıştığım birimdeki herkes } \\
\text { yapabileceği en iyi çabayı gösterir. }\end{array}$ & & & 0,701 & \\
\hline 20 & $\begin{array}{l}\text { Çalıştığım birimde iş kalitesi tüm } \\
\text { çalışanlar için en önemli önceliktir. }\end{array}$ & & & 0,698 & \\
\hline 29 & İş arkadaşlarım oldukça üretkendir. & & & 0,600 & \\
\hline 33 & $\begin{array}{l}\text { İş arkadaşlarım kaynaklardan (para, } \\
\text { insan, ekipman vb.) maksimum çıtı } \\
\text { elde etmede oldukça başarılıdır. }\end{array}$ & & & 0,580 & \\
\hline \multicolumn{6}{|c|}{ Faktör 9 Yaşamsal Memnuniyet } \\
\hline 6 & Hayat şartlarım mükemmeldir. & & & & 0,745 \\
\hline 24 & Yaşamımdan hoşnudum. & & & & 0,650 \\
\hline 27 & Pek çok açıdan ideal bir yaşamım var. & & & & 0,635 \\
\hline 33 & $\begin{array}{l}\text { Hayata yeniden başlama şansım olsa } \\
\text { hayatımdaki hemen hemen hiçbir } \\
\text { şeyi değiştirmezdim. }\end{array}$ & & & & 0,540 \\
\hline
\end{tabular}

Ruhsal Liderlik Ölçüm Aracının faktörleri için bulunan Cronbach's alpha katsayıları Tablo 2'deki gibidir. Görüldüğü üzere boyutlardan 6’sı güçlü, 3’ü düşük güvenilirlik değerine sahiptir.

Tablo 2

Ruhsal Liderlik Ölçeği Faktörleri Cronbach’s Alpha Katsayıları

\begin{tabular}{ll}
\hline Ruhsal Liderlik Ölçeği Alt Boyutları & Cronbach Alpha \\
\hline Vizyon & 0,619 \\
Umut/Çaba & 0,672 \\
Özgecil Sevgi & 0,711 \\
Anlam & 0,769 \\
Üyelik-Aitlik & 0,680 \\
Ruhsal Yaşam & 0,708 \\
Kurumsal Bağlılık & 0,869 \\
Verimlilik & 0,778 \\
Yaşamsal Memnuniyet & 0,981 \\
\hline
\end{tabular}


20 ifadeden oluşan Minnesota İş Tatmini Ölçüm Aracı'nın, araştırmaya katılanlar tarafından bir veya birden fazla boyutlu algılanıp algılanmadığı ve faktör analizine uygunluğu Kaiser-Meyer-Olkin (KMO) testi ile incelenmiştir (Tablo 3).

Tablo 3

Minnesota İş Tatmini Ölçeği KMO ve Barlett Testi

\begin{tabular}{lll}
\hline Kaiser-Meyer-Olkin Örneklemin Uygunluğu Ölçümü (KMO) & 0,916 \\
\hline \multirow{3}{*}{ Bartlett’s Küresellik Testi } & Yaklaşık Ki-Kare $\left(\mathrm{x}^{2}\right)$ & 2770,048 \\
& Serbestlik derecesi (sd) & 190 \\
& $\mathrm{p}$ & $\mathbf{0 , 0 0 0}$ \\
\hline
\end{tabular}

Ölçüm aracı ile toplanan verilerin, faktör analizine uygunluğu için yapılan Kaiser-Meyer-Olkin (KMO) testi sonucu: $\mathrm{KMO}$ değeri, $\mathrm{KMO}=0,916$ olarak bulunduğundan ölçüm aracının faktör analizi için uygun olduğu anlaşılmıştır. KMO uygunluk testi sonrası, Varimax Rotasyon Tekniği kullanılarak yapılan birinci faktör analizi ile ölçüm aracının 20 maddesinin 2 alt boyutta toplandığı ve alt boyutların toplam varyansın \%56,71'sini açıkladıkları bulunmuştur (Tablo 4). Bu analizlerde ilgili yazılımın önerdiği biçimde Öz Değer 1 olarak tercih edilmiştir. Maddelerin hangi faktörlerin içinde yer aldığını belirlerken, minimum yük değeri 0,30 olarak kabul edilmiştir. Maddelerle ilgili olarak tanımlanan iki faktörün ortak varyanslarının (communalities) ise 0,587 ile 0,760 arasında değiştiği gözlenmektedir. Buna göre, analizde literatüre uygun olarak ortaya çıkan iki faktörün, maddelerdeki toplam varyansın ve ölçeğe ilişkin varyansın çoğunluğunu açıladığı görülmektedir. Ancak, ölçüm aracında yer alan 19 (Yaptığım iyi bir iş karşılığında aldığım övgü) ve 20 (İşimden elde ettiğim başarı duygusu) numaralı maddelerinin iki faktörde birden faktör yükü aldığı görülerek, bu maddenin anketten çıkarılmasına karar verilmiştir. Analiz sonucu içsel iş tatmini alt boyutunun toplam varyansın \%37,85'ini, dışsal iç tatmini alt boyutun toplam varyansın \%18,85’ini açıkladığı bulunmuştur.

Tablo 4

Minnesota İş Tatmini Ölçeği Faktör Yükleri

\begin{tabular}{llll}
\hline \multicolumn{2}{l}{ Faktör 1 İçsel İş Tatmini } & 1 & 2 \\
\hline 1 & Sürekli bir şeylerle meşgul olabilme imkânı & 0,704 & \\
2 & Tek başına çalışma imkânı & 0,760 & \\
3 & Zaman zaman farklı şeyler yapabilme imkânı & 0,733 & \\
4 & Toplumda bir yer edinme imkânı & 0,705 & \\
7 & Vicdanıma ters düşmeyen şeyleri yapabilme imkânı & 0,669 & \\
8 & Sürekli bir işe sahip olma imkânı & 0,665 & \\
9 & Başkaları için bir şeyler yapabilme imkânı & 0,646 & \\
10 & Başkalarına ne yapacaklarını söyleme imkânı & 0,636 & \\
11 & Yeteneklerimi kullanabilme imkânı & 0,626 & \\
15 & Kendi kararımı verme özgürlüğü & 0,615 & \\
16 & İş yaparken kendi yöntemlerimi deneme imkânı & 0,605 & \\
\hline Faktör 2 Dışsal İş Tatmini & & 0,697 \\
5 & Yöneticimin elemanlarına karsı davranış tarzı & 0,617 \\
6 & Yöneticimin karar verme konusundaki yeterliliği & & 0,608 \\
12 & Firma politikasını uygulama imkânı & & 0,595 \\
13 & Aldığım ücret & & 0,594 \\
14 & Bu işte ilerleme imkânım & & 0,587 \\
17 & Çalışma koşulları & & \\
18 & Çalışma arkadaşlarımın birbiriyle anlaşması & & \\
\hline & & & \\
\end{tabular}


Minnesota İş Tatmini Ölçüm Aracı ile toplanan veriler için yapılan güvenirlik testinde "İçsel İş Tatmini" Cronbach Alpha katsayısı 0,589; "Dışsal İş Tatmini" Cronbach Alpha katsayısı 0,634; "Genel İş Tatmini”" Cronbach Alpha katsayısı ise 0,678 olarak bulunmuştur (Tablo 5). Söz konusu değerler düşük güvenilirlik seviyesindedir.

Tablo 5

Minnesota İş Tatmini Ölçeği Faktörleri Cronbach’s Alpha Katsayıları

\begin{tabular}{ll}
\hline Ruhsal Liderlik Ölçeği Alt Boyutları & Cronbach's Alpha \\
\hline İçsel İş Tatmini &, 589 \\
Dışsal İş Tatmini &, 634 \\
\hline
\end{tabular}

\section{Bulgular}

Anketleri yanıtlayan 322 kişide sessiz kuşak ve bebek patlaması kuşağına mensup kişi olmadığı görülmüştür. Ankete katılanların 50'si X kuşağı (\%17), 249’u kişi Y kuşağı (\%83) mensubudur. Araştırmaya katılanlardan 23 kişinin Z kuşağında olduğu belirlenmiş ve çalışmanın kapsamı gereği analize dahil edilmemiştir. Araştırmaya katılan çalışanların $\% 43,2$ 'si kadın, \%56,8'i erkektir. Sosyodemografiklere ilişkin yöneltilen diğer sorulara ait bulgular bu çalışmanın kapsamı dışında tutulmuştur.

Araştırma Sorusu 1. Ruhsal liderlik faktörleri ile iş tatmini faktörleri arasında pozitif yönlü bir ilişki var mıdır?

Bu ilk ve temel araştırma sorusuna yanıt vermek açısından,

$\mathrm{H}_{0}$ : İçsel İş Tatmini Ölçeği ile Ruhsal Liderlik Ölçeği alt boyutları arasında ilişki yoktur.

ve

$\mathrm{H}_{0}$ : Dışsal İş Tatmini Ölçeği ile Ruhsal Liderlik Ölçeği alt boyutları arasında ilişki yoktur.

şeklindeki hipotezler, analize konu olan bir çok alt boyutun Kolmogorov-Smirnov sınaması ile 0,05 anlam düzeyinde normal dağılıma sahip olmadığı tespit edildiğinden Spearman sıra korelasyonu yolu ile sınanmıştır.

İş Tatmini Ölçeği "İçsel İş Tatmini" alt boyutu ile Ruhsal Liderlik Ölçeği tüm alt boyutları arasında pozitif yönlü ve anlamlı bir ilişki olduğu tespit edilmiştir. Örnek verileri üzerinden hesaplanan korelasyon katsayıları Tablo 6'da görülmektedir.

Tablo 6

İş Tatmini Ölçeği İçsel Tatmin Boyutu ile Ruhsal Liderlik Ölçeği Boyutları Arasındaki İlişki

\begin{tabular}{lcc}
\hline İş Tatmini Ölçeği "İçsel İş Tatmini" & r & p \\
Ruhsal Liderlik Ölçeği Alt Boyutları & & \\
\hline Vizyon & 0,504 & $0,000^{*}$ \\
Umut/Çaba & 0,587 & $0,000^{*}$ \\
Özveri/Fedakârlık Sevgisi & 0,515 & $0,000^{*}$ \\
Anlam & 0,533 & $0,000^{*}$ \\
Üyelik-Aitlik & 0,590 & $0,000^{*}$ \\
Ruhsal Yaşam & 0,507 & $0,000^{*}$ \\
Kurumsal Bağllılk & 0,541 & $0,000^{*}$ \\
Verimlilik & 0,441 & $0,000^{*}$ \\
Yaşamsal Memnuniyet & 0,494 & $0,000^{*}$ \\
${ }^{*}$ p $<0,000$ & &
\end{tabular}


İş Tatmini Ölçeği "Dışsal İş Tatmini" alt boyutu ile Ruhsal Liderlik Ölçeği tüm alt boyutları arasında pozitif yönlü ve anlamlı bir ilişki olduğu tespit edilmiştir. Örnek verileri üzerinden hesaplanan korelasyon katsayıları Tablo 7'de görülmektedir.

Tablo 7

İş Tatmini Ölçeği Dışsal Tatmin Boyutu ile Ruhsal Liderlik Ölçeği Boyutları Arasındaki İlişki

\begin{tabular}{lcc}
\hline İş Tatmini Ölçeği "Dısssal İş Tatmini" & $\mathbf{r}$ & $\mathbf{p}$ \\
Ruhsal Liderlik Ölçeği Alt Boyutları & & \\
\hline Vizyon & 0,643 & $0,000^{*}$ \\
Umut/Çaba & 0,586 & $0,000^{*}$ \\
Özveri/Fedakârlık Sevgisi & 0,756 & $0,000^{*}$ \\
Anlam & 0,433 & $0,000^{*}$ \\
Üyelik-Aitlik & 0,737 & $0,000^{*}$ \\
Ruhsal Yaşam & 0,484 & $0,000^{*}$ \\
Kurumsal Bağlıık & 0,718 & $0,000^{*}$ \\
Verimlilik & 0,585 & $0,000^{*}$ \\
Yaşamsal Memnuniyet & 0,685 & $0,000^{*}$ \\
${ }^{*}<0,000$ & &
\end{tabular}

\section{Araştırma Sorusu 2. X ve Y kuşağının ruhsal liderlik algıları farklııı göstermekte midir?}

Bu ikincil araştırma sorusuna yanıt vermek açısından,

$\mathrm{H}_{0}$ : X kuşağı ile Y kuşağı arasında ruhsal liderlik algısı açısından anlamlı fark yoktur.

şeklindeki hipotez Kruskal Wallis sınaması ile test edilmiştir. Sonuçlar Tablo 8'de görülmektedir.

Katılımcıların ait oldukları kuşağa göre ruhsal liderlik puanlarının farklılaşıp farklılaşmadığını belirlemek üzere uygulanan Kruskal Wallis Testi sonuçları, (Tablo 8) Ruhsal Liderlik "Vizyon"; “Anlam”; “Üyelik/Aitlik”; "Verimlik" ve "Yaşamsal Memnuniyet" alt boyutlarından aldıkları puanlara göre anlamlı şekilde farklılaştığını göstermektedir. Puanlar sirasıyla; $\mathrm{x}^{2}(\mathrm{sd}=2, \mathrm{n}=313)=8,600 \mathrm{p}<0,05 ; \mathrm{x}^{2}(\mathrm{sd}=2, \mathrm{n}=313)=10,143 \mathrm{p}<0,01 ; \mathrm{x}^{2}(\mathrm{sd}=$ $2, \mathrm{n}=313)=10,315 \mathrm{p}<0,01 ; \mathrm{x}^{2}(\mathrm{sd}=2, \mathrm{n}=313)=11,237 \mathrm{p}<0,01 ; \mathrm{x}^{2}(\mathrm{sd}=2, \mathrm{n}=313)=8,472 \mathrm{p}<0,05$ şeklindedir. Elde edilen bu bulgular, katılımcıların ait oldukları kuşağın Ruhsal Liderlik "Vizyon"; “Anlam"; "Üyelik/Aitlik"; "Verimlik" ve "Yaşamsal Memnuniyet" alt boyutlarından aldıkları puanları arttırmada farklı etkilere sahip olduğunu göstermektedir. 
Tablo 8

Katılımcıların Ait Olduğu Kuşağa Göre Ruhsal Liderlik Puanları Karşılaştırması (Kruskal Wallis Testi Sonuçları)

\begin{tabular}{|c|c|c|c|c|c|c|}
\hline $\begin{array}{l}\text { Ruhsal Liderlik } \\
\text { Ölçeği Alt Boyutları }\end{array}$ & Gruplar "Kuşak" & $\mathbf{N}$ & $\begin{array}{c}\text { Siralar } \\
\text { Ortalaması }\end{array}$ & Kikare & Sd & $\mathbf{p}$ \\
\hline \multirow{2}{*}{ Vizyon } & X Kuşağg 1 (1965-1979) & 50 & 131,78 & & \multirow{2}{*}{2} & \multirow{2}{*}{$0,014^{* * x}$} \\
\hline & Y Kuşağ 1 (1980-1999) & 249 & 159,32 & & & \\
\hline \multirow{2}{*}{ Umut/Çaba } & X Kuşağg (1965-1979) & 50 & 140,08 & \multirow[b]{2}{*}{5,748} & \multirow[b]{2}{*}{2} & \multirow{2}{*}{0,056} \\
\hline & Y Kuşağ 1 (1980-1999) & 249 & 157,78 & & & \\
\hline \multirow{2}{*}{ Özgecil Sevgi } & X Kuşağg 1 (1965-1979) & 50 & 132,20 & \multirow{2}{*}{4,643} & \multirow{2}{*}{2} & \multirow{2}{*}{0,098} \\
\hline & Y Kuşağg $(1980-1999)$ & 249 & 161,95 & & & \\
\hline \multirow{2}{*}{ Anlam } & X Kuşağg (1965-1979) & 50 & 147,48 & \multirow{2}{*}{10,143} & \multirow{2}{*}{2} & \multirow{2}{*}{$0,006^{\star}$} \\
\hline & Y Kuşağ 1 (1980-1999) & 249 & 154,81 & & & \\
\hline \multirow{2}{*}{ Üyelik-Aitlik } & X Kuşağg (1965-1979) & 50 & 124,74 & \multirow{2}{*}{10,315} & \multirow{2}{*}{2} & \multirow{2}{*}{$0,006^{\star}$} \\
\hline & Y Kuşağg (1980-1999) & 249 & 161,11 & & & \\
\hline \multirow{2}{*}{ Ruhsal Yaşam } & X Kuşağg 1 (1965-1979) & 50 & 135,22 & \multirow{2}{*}{5,512} & \multirow{2}{*}{2} & \multirow{2}{*}{0,064} \\
\hline & Y Kuşağı (1980-1999) & 249 & 159,30 & & & \\
\hline \multirow{2}{*}{ Kurumsal Bağll1lk } & X Kuşağg 1 (1965-1979) & 50 & 133,68 & \multirow{2}{*}{5,100} & \multirow{2}{*}{2} & \multirow{2}{*}{0,078} \\
\hline & Y Kuşağ 1 (1980-1999) & 249 & 160,09 & & & \\
\hline \multirow{2}{*}{ Verimlilik } & X Kuşağı (1965-1979) & 50 & 119,73 & \multirow{2}{*}{11,237} & \multirow{2}{*}{2} & \multirow{2}{*}{$0,004^{\times}$} \\
\hline & Y Kuşağg (1980-1999) & 249 & 163,08 & & & \\
\hline Yaşamsal & X Kuşağg (1965-1979) & 50 & 124,09 & \multirow{2}{*}{8,472} & \multirow{2}{*}{2} & \multirow{2}{*}{$0,014^{* * x}$} \\
\hline Memnuniyet & Y Kuşağ 1 (1980-1999) & 249 & 162,37 & & & \\
\hline
\end{tabular}

Katılımcıların "Vizyon"; “Anlam"; “Üyelik/Aitlik"; ”Verimlilik" ve "Yaşamsal Memnuniyet” alt boyutlarının grup sıralar ortalamaları dikkate alındığında; 1980-1999 doğumlu katılımcıların (Y kuşağının) puanını 19651979 doğumlu katılımcıların (X kuşağı) takip ettiği tespit edilmiştir. Son olarak ise Ruhsal Liderlik Ölçeği "Umut/Çaba”, “Özgecil Sevgi”, "Ruhsal Yaşam” ve "Kurumsal Bağlllık” alt boyut puanlarından elde edilen puanların, katılımcıların ait oldukları kuşağa göre anlamlı bir farklılaşma göstermediği tespit edilmiştir. Polat'ın (2011) yürüttüğü bir çalışmaya göre ruhsal (manevi) liderlik, organizasyonel hedefleri başarmada önemli bir etkendir. Polat'ın Kocaeli Üniversitesi son sinıfta okuyan 432 öğrenci üzerinde gerçekleştirdiği çalışma sonucunda, akademisyenlerin, öğrencilerden farklı olarak inanç ve vizyondan ziyade özgecil sevgi tutumu gösterdikleri ortaya çıkmıştır. Bu çalışmada ise özgecil sevgi değil, vizyon ve yaşamsal memnuniyet boyutları Y kuşağı lehine farklılık göstermiştir (Tablo 8).

\section{Araştırma Sorusu 3. $X$ ve $Y$ kuşağının iş tatmini düzeyleri farklılık göstermekte midir?}

$\mathrm{Bu}$ ikincil araştırma sorusuna yanıt vermek açısından,

$\mathrm{H}_{0}$ : $\mathrm{X}$ kuşağı ile $\mathrm{Y}$ kuşağı arasında iş tatmini düzeyi açısından anlamlı fark yoktur.

şeklindeki hipotez Kruskal Wallis sınaması ile test edilmiştir. Sonuçlar Tablo 9'da görülmektedir.

Katılımcıların ait oldukları kuşağa göre iş tatmini puanlarının farklılaşıp farklılaşmadığını belirlemek üzere uygulanan Kruskal Wallis testi sonuçları (Tablo 9); katılımcıların İş Tatmini "İçsel İş Tatmini" alt boyutlarından aldıkları puanların katılımcıların ait olduğu kuşak değişkenine göre anlamı bir şekilde farklılaştığını göstermektedir. Elde edilen bu bulgu, katılımcıların hangi kuşağa ait olduklarının İş Tatmini "İçsel İş Tatmini" alt boyutlarından aldıkları puanları arttırmada farklı etkilere sahip olduğunu göstermektedir. 
Tablo 9'da görüldügü üzere X kuşağının içsel iş tatmini Y kuşağına göre daha yüksektir. Dolayısıyla, literatürde yaş arttıkça iş tatminin de artacağı bulgularıyla (Marschke ve ark., 2011) paralellik söz konusudur.

Tablo 9

Katılımcıların Ait Olduğu Kuşağa Göre İş Tatmini Puanları Karşılaştırması (Kruskal Wallis Testi Sonuçları)

\begin{tabular}{|c|c|c|c|c|c|c|}
\hline $\begin{array}{l}\text { İş Tatmini } \\
\text { Ölçeği Alt } \\
\text { Boyutları }\end{array}$ & Gruplar "Kuşak" & $\mathbf{N}$ & $\begin{array}{c}\text { Siralar } \\
\text { Ortalaması }\end{array}$ & Kikare & Sd & $\mathbf{p}$ \\
\hline İçsel İş & X Kuşağ 1 (1965-1979) & 50 & 160,93 & & \multirow{2}{*}{2} & \multirow{2}{*}{$0,014^{*}$} \\
\hline Tatmini & Y Kuşağı (1980-1999) & 249 & 152,42 & & & \\
\hline Dişsal İș & X Kuşağ 1 (1965-1979) & 50 & 141,98 & \multirow{2}{*}{1,797} & \multirow{2}{*}{2} & \multirow{2}{*}{0,407} \\
\hline Tatmini & Y Kuşağı 1 (1980-1999) & 249 & 160,35 & & & \\
\hline
\end{tabular}

\section{Sonuç}

Ruhsal liderlik, bugünün kaotik iş ortamında hayatta kalmak için önem teşkil etmektedir. Vizyonlarını geliştirmeyi hedefleyen örgütler için motivasyon kaynağ 1 olan ruhsal liderlik, performansı arttırarak iş tatminini yükseltmektedir. Yine çalışanların iş tatmini, yüksek performansın çok önemli bir belirleyicisidir.

Katılımcıların Ruhsal Liderlik "Vizyon" ve "Yaşamsal Memnuniyet" alt boyutlarından aldıkları puanların katılımcıların ait oldukları kuşak değişkenine göre anlamı bir şekilde farklılaştığı tespit edilmiştir. Diğer bir ifadeyle $\mathrm{Y}$ kuşağı, liderlerinden vizyon ve yaşamsal memnuniyet anlamında $\mathrm{X}$ kuşağından daha fazla beklenti içindedir. Bu durum gençlerin ileriye yönelik daha çok beklentilerinin olması ve iş-yaşam dengesi kurarak daha çok hayatlarından memnun olmak istemeleri şeklinde yorumlanabilir. Bu bağlamda ülkemizde çalışma hayatının düzenlenmesinde ve yönetim politikalarının belirlenmesinde yurtdışı yayınlar temel alınarak,kuşakların yönetim algılarının ve liderlik tarzı beklentilerinin daha derinlemesine araştırılmasının ve analiz edilmesinin önem taşıdığı düşünülmektedir.

Çalışmada, katılımcıların İş Tatmini "İçsel İş Tatmini" alt boyutlarından aldıkları puanların X kuşağı lehine anlamlı bir şekilde farklılaştığı görülmektedir. Literatürde yaş arttıkça iş tatminin de artacağı bulgularıyla (Marschke ve ark., 2011) paralellik gösteren bu durum, yaş ilerledikçe artan sorumluluklardan kaynaklanabileceği gibi, artık gençler kadar kolay iş değiştirme yeteneğinin kalmadığının düşünülmesi kaynaklı olabilir.

Gösterilen ruhsal liderlik ve iş tatmini algısı davranışının sadece birey ve onun ait olduğu kuşak, ya da sosyodemografik özelliklerden kaynaklanmadığı, yalnızca yaptığı iş gereği olabileceği de düşünülmelidir. Araştırmacılara bu boyutu dikkate alan bir çalışma yapmaları önerilebilir. Diğer çalışmalar gibi bu çalışmanın da kısıtları mevcuttur. Çalışmada tüm X ve Y kuşağı mensuplarının dahil edilememiş olması genellenebilirlik özelliğini düşürmektedir. Yine de bu çalışma kuşakların ruhsal liderlik ve iş tatmini algılarını anlamak adına yol gösterici niteliktedir. Daha sonra yapılacak çalışmalarda örneklem büyüklüğü arttırılarak genel geçerlilik arttırılabilir. Nitel çalışma ile de desteklenebilecek çalışmalarla daha sağlıklı veriler elde edilebilir. X ve Y Kuşağı bireylerinin ruhsal liderlik ve iş tatmini farklılıklarının incelenmesi amacıyla yürütülen bu araştırma hem araştırmacılara hem de iş dünyasındaki profesyonellere katkı sağlayabilecek niteliktedir. Bu araştırmanın literatüre yaptığı en önemli katkı, yöneticilerin örgüt iklimlendirmesinde $\mathrm{X}$ ve Y kuşağı özelliklerini dikkate alabilmeleri adına yol gösterici olmasıdır. Ruhsal liderliğin iş tatminine etkisi göz önünde bulundurularak bu iklimin oluşturulması için her türlü örgütsel desteğin sağlanması gerektiği anlaşılmalıdır. 


\section{Kaynakça}

Acılıoğlu, İ. (2015). İş'te Y kuşağı. Ankara: Elma Yayınevi.

Adıgüzel, O., Batur, H. Z. ve Ekşili N. (2014). Kuşakların değişen yüzü ve Y kuşağı ile ortaya çıkan yeni çalışma tarzı: Mobil yakalılar. Süleyman Demirel Üniversitesi Sosyal Bilimler Enstitüsü Dergisi, 1(19), 165-182. Erişim adresi: https://dergipark.org.tr/tr/download/article-file/215113

Allen, C. L. (1972). The miracle of love. Old tappan. New Jersey: Fleming H. Revell.

Alwin, D. F. (2002). Generations X, Y and Z: Are they changing America? American Sociological Association, 42(1), 42-51. doi: 10.1525\%2Fctx.2002.1.4.42

Aslan-Yılmaz, H. ve Dönmez, A. (2013). İş doyumunu tayin eden bazı psikolojik ve demografik değişkenler. Türk Psikoloji Yazılar, $16(31), \quad$ 91-97. Erişim adresi: https://www.researchgate.net/publication/321824211_AslanYilmaz_H_Donmez_A_2013_Is_Doyumu nu_Tayin_Eden_Psikolojik_Bazi_Psikolojik_ve_Demografik_Degiskenler_Turk_Psikoloji_Yazilari_16 31_91-97

Aşık, N. A. (2010). Çalışanların iş doyumunu etkileyen bireysel ve etkisel faktörler ile sonuçlarına ilişkin kavramsal bir değerlendirme. Türk İdare Dergisi, 1(467), 31-51. Erişim adresi: http://www.tid.gov.tr/makaleler/467nuranaksit.pdf

Baloğlu, N. ve Karadağ, E. (2009). Ruhsal liderlik üzerine teorik bir çözümleme. Educational Administration: Theory and Practice, 15(58), 165-190. Erişim adresi: https://dergipark.org.tr/en/pub/kuey/issue/10339/126680

Bogler, R. (2001). The influence of leadership style on teacher job satisfaction. Educational Administration Quarterly, 37, 657-681. doi: 10.1177\%2F00131610121969460

Chen, C. Y. ve Yang, C. F. (2012). The impact of spiritual leadership on organizational citizenship behavior: A multi-sample analysis. Journal Business Ethics, 105, 107-114. doi: 10.1007/s10551-011-0953-3

Cook-Greuter, S. (2002). A detailed description of the development of nine action logics. Nine Action Logics and Their Development in Detail. Erişim adresi: http://nextstepintegral.org/wpcontent/uploads/2011/04/The-development-of-action-logics-Cook-Greuter.pdf

Corgnet, B. Gomez-Minambres, J. ve Hernan-Gonzâles, R. (2015). Goal setting and monetary incentives: When large stakes are not enough. Management Science, 61(12), 2926-2944. doi: https://econpapers.repec.org/scripts/redir.pf?u=http\%3A\%2F\%2Fdx.doi.org\%2F10.1287\%2Fmnsc.201 4.2068;h=repec:inm:ormnsc:v:61:y:2015:i:12:p:2926-2944

Demircioğlu, E. M. (2015). Karizmatik liderliğin yönetsel açıdan değerlendirilmesi. Uluslararası Akademik Yönetim Bilimleri Dergisi, 1(1), 52-69. Erişim adresi: https://dergipark.org.tr/en/download/articlefile/626319

Dent, E. B., Higgins, M. E. ve Wharf, D. M. (2005). Spirituality and leadership: An empirical review of definitions, distinctions and embedded assumptions. The Leadership Quarterly, 16, 625-653. doi: 10.1016/j.leaqua.2005.07.002

Deutsch, M. (1975). Equity, equality, and need: what determines which values will be used as determinants of distributive justice? Journal of Social Issues, 31, 137-149. doi: 10.1111/j.1540-4560.1975.tb01000.x

Dias, L. P. (2003). Generational buying motivations for fashion. Journal of Fashion Marketing and Management, 7(1): 78-86. Erişim adresi: https://ivypanda.com/essays/generational- buyingmotivations-for-fashion-by-laura-portolese-dias-essay/ 
Eren, E. (2014). Örgütsel davranışve yönetim psikolojisi. İstanbul: Beta Yayınevi.

Farrell, D., Ferraris, L., King, I., Paradi, A., Robertson, A. ve Rossi, L. Siccardi, F. (2011). The enhancing resilience to reduce vulnerability in the Caribbean region project. Plinius Conference Abstracts, Erişim adresi: https://meetingorganizer.copernicus. org/Plinius13/Plinius13-128.pdf

Feldman, D. C. ve Arnold, H. J. (1985). Managing individual and group behavior in organizations. London: McGraw-Hill Book Company.

Freeman, G. T. (2011). Spirituality and servant leadership: A conceptual model and research proposal. Emerging Leadership Journeys, 4(1), 120-140. Erişim adresi: https://www.regent.edu/acad/global/publications/elj/vol4iss1/Freeman_V4I1_pp120-140.pdf

Friday, S. S. ve Friday, E. (2003). Racioethnic perceptions of job characteristics and job satisfaction. Journal of Management Development, 22(5), 426-442. doi: 10.1108/02621710310474778

Fry, L. W. (2003). Toward a theory of spiritual leadership. The Leadership Quarterly, 14, 693-727. doi: 10.1016/j.leaqua.2003.09.001

Fry, L. W., Latham, J. R., Clinebell, S. K. ve Krahnke, K. (2017), Spiritual leadership as a model for performance excellence: A study of baldrige award recipients. Journal of Management, Spirituality and Religion, 14(1), 22-47. doi: $10.1080 / 14766086.2016 .1202130$

Gemmil, G. R. ve Heisler, W. J. (1972). Machiavellianism as a factor in managerial job strain, job satisfaction, and upward mobility. Academy of Management Journal,15 (1), 51-62. doi: 10.2307/254800

Giacalone, R. A. ve Jurkiewicz, C. L. (2003). Handbook of Workplace Spirituality and Organizational Performance. R. A. Giacalone ve C. L. Jurkiewicz (Ed.), New York: M. E. Sharp.

Goleman, D. (2007). İş başında duygusal zekâ (5. Baskı). Türkçeleştiren: Handan Balkara, Redaksiyon: Filiz Deniztekin - Osman Deniztekin, İstanbul: Varlık Yayınları.

Gündüz, Ş. (2016). Ruhsal liderlik ile iş tatmini arasındaki ilişki: Duygusal zekânın aracı etkisi (Yayınlanmamış Doktora Tezi), Marmara Üniversitesi Sosyal Bilimler Enstitüsü.

Gündüz, Ş. (2017). The relationship between spiritual leadership and organizational cynicism: The moderating effect of emotional intelligence. Doğuş University Journal, 18(2), 117-132. Erişim adresi: http://openaccess.maltepe.edu.tr/xmlui/handle/20.500.12415/3954

Harvard Business School Publishing (2015). Liderlik (Çev.: M. İnan). İstanbul: Optimist Yayınları.

Hina, A., Fani, M. İ., Huma, A. ve Shahab, S. (2013). Impact of gender diversity on spiritual leadership and follower's need for spiritual survival/well-being. African Journal of

Business Management, 7(39), 4122-4127. doi: 10.5897/AJBM11.2235

Hoppock, R. (1935). Job satisfaction. New York and London: Harper and Brothers.

Hürriyet, (2028). Bigpara. Erişim tarihi: http://bigpara.hurriyet.com.tr/haberler/ekonomi-haberleri/isteturkiyenin-en-buyuk-sirketleriID1447259/

Juhaizi, M. Y. ve Izah, M. T. (2011). Spiritual leadership and job satisfaction: A proposed conceptual framework. Information Management and Business Review, 6(2), 239-245. Erişim adresi: https://econpapers.repec.org/scripts/redir.pf?u=http\%3A\%2F\%2Fwww.internationalconference.com. my\%2Fproceeding\%2F2ndicber2011_proceeding\%2F471-

2nd\%2520ICBER\%25202011\%2520PG\%252024612479\%2520Multidimensional\%2520Approach.pdf;h =repec:cms:2icb11:2011-471 
Koç, M., Öztürk, L. ve Yildirim, A. (2016). A study on job satisfaction and organisational commitment of X and Y generations. Research Journal of Business and Management, 3(2), 173-183. Erişim adresi: https://dergipark.org.tr/en/pub/rjbm/issue/23910/254820

Lawler III, E. E., ve Porter, L. W, (1967). The effect of performance on job satisfaction. Industrial Relations, 7(1), 20-28. doi: 10.1111/j.1468-232X.1967.tb01060.x

Lehto, Y. X., Jang, S., Francis, A. ve O'leary, J. (2008). Exploring tourism experience sought: A cohort comparison of baby boomers and the silent generation. Journal of Vacation Marketing, 14(3), 237-252. doi: 10.1.1.1027.798

Levickaite, R. (2010). Generations X Y Z: How social networks form the concept of the world without borders the case of Lithuania. Limes, 3(2), 170-183. doi: 10.3846/limes.2010.17

Locke E. A. (1976). The nature and causes of job satisfaction. In M. D. Dunnette (Ed.), Handbook of Industrial and Organizational Psychology. Chicago: Rand McNally.

Marschke, E., Preziosi, R. ve Harrington, W. J. (2011). How sales personnel view the relationship between job satisfaction and spirituality in the workplace. Journal of Organizational Culture, Communications and Conflict, 15(2), 71-110. Erişim adresi: https://www.researchgate.net

Marx, G. (2006). Future-Focused leadership: Preparing schools, Students, and for tomorrow's realities. Alexandria: Libra Publishers.

Mengi, Z. (2018), İş başarısında kuşak farkı. Erişim adresi: www.kigem.com/is-basarisinda-kusak-farki

Moxley, R. S. (2000). Leadership and spirit. San Francisco: Jossey-Bass.

Mucuk, İ. (2003). Modern işletmecilik. İstanbul: Türkmen Kitabevi.

Mullıns, L. J. (1996). Management and organizational behaviour. Fourth ed., London: Pitmon Publishing.

Özdemir, B., Yılmaz, G. ve Ülker, M. (2016). The relationships among socio-demographic characteristics, behaviours and motivations of festival attendees: A study in Urla International Grape Harvest Festival. 6th International Conference on Tourism (ICOT 2016), Napoli, İtalya, 29.06.2016-02.07.2016, 1(1), 323337.

Özer S. P., Eriş, E. D. ve Özmen-Timurcanday, Ö. N. (2013). Kuşakların farklılaşan iş değerlerine ilişkin emik bir araştırma. Dumlupınar Üniversitesi Sosyal Bilimler Dergisi, 38(1), 123-138. Erişim adresi: https://dergipark.org.tr/en/pub/dpusbe/issue/4780/65888

Özpehlivan, M. (2018). İş tatmini: Kavramsal gelişimi, bireysel ve örgütsel etkileri, yararları ve sonuçları. Kırklareli Üniversitesi Sosyal Bilimler Dergisi, 2(2), 43-70. Erişim adresi: https://dergipark.org.tr/en/pub/kusbder/issue/42811/474446

Parameshwar, S. (2005), Spiritual leadership through egotranscendence: Exceptional responses to challenging circumstances. The Leadership Quarterly, 16, 689-722. doi: 10.1016/j.leaqua.2005.07.004

Polat, S. (2011). The level of faculty members' spiritual leadership (SL) qualities display according to students in Faculty of Education. Procedia - Social and Behavioral Sciences, 15, 2033-2041. doi: 10.1016/j.sbspro.2011.04.049

Pratt, M. (2000). Building an ideological fortress: The role of spirituality, encapsulation and sense making. Studies in cultures. Organizations and Societies, 6(1), 35-53. doi: 10.1080/10245280008523537

Rose, G. M., Merchannt, A., Orth, U. R. ve Horstmann, F. (2016). Emphasizing brand heritage: Does it work? And how? Journal Business Research, 69, 936-943. doi: 10.1016/j.jbusres.2015.06.021 
Sanders, J. E., Hopkins, W. E. ve Geroy, G. D. (2003). From transactional to transcendental: toward an integrated theory of leadership. Journal of Leadership and Organizational Studies, 9(4), 21-31. doi: $10.1177 / 107179190300900402$

Serikan, C. (2012). Liderlik ve motivasyon: Geleneksel ve güncel yaklaşımlar. Ankara: Nobel Yayın Dağıtım.

Strack, G, Fottler, M., Wheatley, M. ve Sodomka, P. (2002). Spirituality and effective leadership in healthcare: Is there a connection? Frontiers of Health Service Management, 18(4), 3-45. doi: 10.1097/01974520200204000-00002

Toker, B. (2007). Demografik değişkenlerin iş tatminine etkileri: İzmir'deki beş ve dört yıldızlı otellere ilişkin bir uygulama. Doğuş Üniversitesi Dergisi, 8(1), 92-107. Erişim adresi: http://journal.dogus.edu.tr/index.php/duj/article/view/102

Tolbize, A. (2008). Generational differences in the workplace. University of Minnesota, Research and Training Center on Community Living. Erişim adresi: http://rtc.umn.edu/docs/2_18_Gen_diff_workplace.pdf

Toruntay, H. (2011). Takım rolleri çalışmast: X ve Y kuşağ ü̈erinde karşılaş̧ırmalı bir araştırma. (Yayımlanmamıs, Yüksek Lisans Tezi), İstanbul Üniversitesi, Sosyal Bilimler $\quad$ Enstitüsü.

Türk Dil Kurumu (TDK), (2019). Güncel Türkçe sözlük. Erişim adresi: http://www.tdk.gov.tr/

Ülker, F. ve Özdemir, G. (2016). İş tatmininin örgütsel bağlllığa olan etkisi: Kooperatif işletmeler örneği. Yönetim Bilimleri Dergisi, 14(27), 331-352. Erişim adresi: https://dergipark.org.tr/en/pub/comuybd/issue/43601/533929

Vecchio, R. P. (1988). Organizational Behavior. Orlando: The Dreyden Press.

Vroom, V. H. (1964), Work and Motivation. New York: Wiley.

Weng, R. H., Huang, C. Y., Chen, L. M. ve Chang, L. Y. (2015). Exploring the impact of transformational leadership on nurse innovation behaviour: A cross sectional study. Journal Nursing Management, 23, 427-439. doi: 10.1111/jonm. 12149

Wnuk, M. (2017). Organizational conditioning of job satisfaction: A model of job satisfaction. Contemporary Economics, 12(1), 31-44. doi: 10.5709/ce.1897-9254.227

Yang, F., Liu, J., Wang, Z. ve Zhang, Y. (2017). Feeling energized: A multilevel model of spiritual leadership, leader integrity, relational energy, and job performance. Journal Business Ethics, 145, 1-5. doi: 10.1007/s10551-017-3713-1

Zemke, R., Rainess, C. ve Filipczak, B. (2013). Generations at work: Managing the clash of boomers, gen Xers, and gen Yers in the workplace. 2nd Ed., USA: Amacom.

\section{Extended Abstract}

\section{Purpose}

In the intensive and complex structure of business life the management discipline has directed its attention to what could make the workplace life more meaningful, thus research on spiritual leadership has increased. There are many studies that investigate the factors that may affect employees' job satisfaction, especially the relationship between leadership and job satisfaction. In this context, examining the relationship between spiritual leadership and job satisfaction will contribute to the current literature. Identifying the differences between the perceptions of spiritual leadership and job satisfaction between generations in business life, where different generations work together, can be a guide for business discipline and professionals. The aim of this 
study is to examine the effect of spiritual leadership on job satisfaction in different generations. This study bases spirituality as an integral part of leadership and traces the relationship between spiritual leadership and job satisfaction.

\section{Design and Methodology}

This study was designed to investigate whether the Spiritual Leadership and Job Satisfaction differ according to sociodemographic factors. Fry's 40-item Spiritual Leadership Scale and 18-item Minnesota Job Satisfaction Scale were used. Following a pilot study with 30 participants, KMO values were found 0,957 and 0,916 respectively.

After the Kaiser-Meyer-Olkin (KMO) suitability test with Varimax Rotation Technique for Spiritual Leadership Scale, it was found that 40 items of the measurement tool were gathered in 9 sub-dimensions and the sub-dimensions explained $79.63 \%$ of the total variance. The communalities of the nine factors vary between 0.402 and 0.764 . Accordingly, it is seen that nine factors that appeared in parallel with Fry's scale in the analysis explained the majority of the total variance.

The result of KMO test made for the suitability of the data collected with the 18-item Minnesota Job Satisfaction was found 0.916 . The factor analysis with Varimax Rotation Technique showed 20 items were gathered in 2 sub-dimensions explaining $56.71 \%$ of the total variance. The communalities vary between 0.587 and 0.760 . Accordingly, it is seen that two factors explain the majority of the total variance in the items in accordance with the literature

The sample size was calculated as 246 considering the size of the universe ( 1 million working people in BİST 500 firms in Istanbul). In case the return to the questionnaire would be delayed, 400 questionnaires were distributed and 322 responses were provided. The data obtained through the questionnaire form were analyzed in the "SPSS for Windows 22.0" program.

While the dependent variable of the study is job satisfaction, the independent variable is the socio-demographic characteristics of the Generations $\mathrm{X}$ and $\mathrm{Y}$. In this study, the following research questions were created in order to determine how important spiritual leadership is in the Generations $\mathrm{X}$ and $\mathrm{Y}$ and whether there is a significant difference in job satisfaction between the two generations:

1)Is there a positive relationship between spiritual leadership factors and job satisfaction factors?

2)Do the spiritual leadership perceptions of the Generations $X$ and $Y$ differ?

3)Do the job satisfaction levels of the Generations $X$ and $Y$ differ?

\section{Findings:}

H0: There is no relationship between Internal Job Satisfaction Scale and the sub-dimensions of Spiritual Leadership Scale.

H0: There is no relationship between External Job Satisfaction Scale and the sub-dimensions of the Spiritual Leadership Scale.

hypotheses were tested by Spearman rank correlation as it had been determined that they did not have a normal distribution at 0.05 significance level by Kolmogorov-Smirnov test. A positive and significant relationship was found between the "Internal Job Satisfaction" sub-dimension of Job Satisfaction Scale and all sub-dimensions of Spiritual Leadership Scale. A positive and significant relationship was found between "External Job Satisfaction" sub-dimension in the sub-dimensions "Vision", "Meaning", "Membership / Belonging", "Efficiency" and "Vital Satisfaction".

H0: There is no significant difference between the Generation $\mathrm{X}$ and the Generation $\mathrm{Y}$ in terms of the perception of spiritual leadership. 
hypothesis was tested with the Kruskal Wallis test, which shows the scores of "Vision", "Meaning", "Membership / Belonging", "Efficiency" and "Vital Satisfaction" sub-dimensions differ.

H0: There is no significant difference between the Generation X and Generation Y in terms of job satisfaction.

hypothesis was tested with the Kruskal Wallis test to determine whether the job satisfaction scores of the participants differ according to the generation they belong to, which shows that the scores of the participants' "Internal Job Satisfaction" sub-dimensions differs in a meaningful way according to the generations to which the participants belong. This finding shows that the generation of the participants has different effects on increasing their scores from the "Internal Job Satisfaction" sub-dimensions. In other words, the internal job satisfaction of the Generation X is higher than the Generation Y, which is parallel to the literature (Marschke et al., 2011)

In the literature, it is stated that the job satisfaction level of Generation X is higher than that of Generation $\mathrm{Y}$ (Koç et al., 2016, p.181). This study, which refers to the effect of spiritual leadership on job satisfaction over different generations reveals that there is a partial difference between the perceptions of spiritual leadership and job satisfaction of the Generations X and Y. It was once again seen that spiritual leadership positively affects job satisfaction, in support of the literature.

\section{Research Limitations}

Although the universe of the research is all employees, the limitation of this study is the employees in BIST 500 companies, and the majority of the participants in the research are private sector employees. The lack of equal participation from both public and private sectors created a research constraint. It is assumed that the items in the scales are understood correctly by the participants, the answers reflect the truth and are given without any pressure.

The fact that all generation $\mathrm{X}$ and $\mathrm{Y}$ members were not included in the study decreases the generalizability feature. Nevertheless, this study is a guide for understanding the perceptions of spiritual leadership and job satisfaction of generations.

\section{Implications}

It should also be considered that spiritual leadership and job satisfaction perception behavior shown is not only due to the individual and the generation to which they belong, or sociodemographic characteristics, but may only be due to their job. A study that takes this dimension into account is suggested for the researchers. The general validity can be increased by increasing the sample size in future studies. Healthier data can be obtained with studies that can also be supported by qualitative studies.

\section{Originality}

There are many studies in the literature on how job satisfaction varies in terms of age, one of demographic characters. Most of these studies show that job satisfaction increases as age increases. In this study, it is aimed to contribute to existing literature by specifying the age variable with the distinction between Generations $\mathrm{X}$ and Y.

This research, which is conducted to examine the differences in spiritual leadership and job satisfaction of Generation $\mathrm{X}$ and $\mathrm{Y}$ individuals, can contribute to both researchers and professionals. The most important contribution of this research to the literature is that it is a guide for managers to take into account the characteristics of the Generations X and Y in organizational conditioning. Considering the impact of spiritual leadership on job satisfaction, it should be understood that all kinds of organizational support should be provided to create this climate.

Araştırmacı Katkısı: Alper DEMİRDAĞ (\%50), Şafak GÜNDÜZ (\%50). 